\title{
Krzysztof Gawlikowski
}
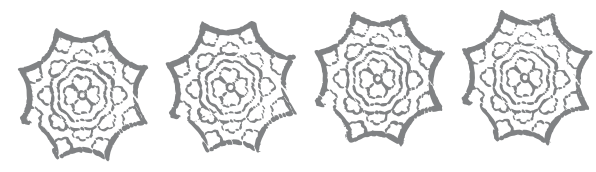

\section{NOWE POLSKIE CZASOPISMO O CHINACH}

Nie często się zdarza pojawienie w Polsce nowego czasopisma o Azji, tym bardziej poważnego i bardzo wartościowego. „Chiny dzisiaj: Religie - Chrześcijaństwo - Kościół" to kwartalny biuletyn informacyjny wydawany przez Komisję Episkopatu Polski ds. Misji, Polską Prowincję Zgromadzenia Słowa Bożego (Societas Verbi Dei, SVD) oraz Prowincję Chrystusa Króla Stowarzyszenia Apostolstwa Katolickiego. Można mieć nadzieję, że taki zespół katolickich podmiotów zapewni pismu stabilność finansową i organizacyjną. W 2006 r. ukazał się pierwszy, sygnalny numer, a w 2007 r. do jesieni ukazały się trzy numery, z których każdy liczy po 52 strony. Można zatem to czasopismo już uznać za zjawisko trwałe na polskim rynku wydawniczym.

O sukcesie przedsięwzięcia i wysokim poziomie pisma przesądziło zapewne przyjęcie funkcji Redaktora Naczelnego przez dr Romana Malka, SVD, jednego z najwybitniejszych sinologów polskich, od wielu lat pracującego głównie w Niemczech. Jest on obecnie dyrektorem zasłużonego Instytutu Monumenta Serica w St. Augustin koło Bonn i Redaktorem Naczelnym wydawanego tam pisma „Monumenta Serica - Journal of Oriental Studies" (jego tomy ukazują się raz na rok). Instytut ten wydaje także dwie specjalistyczne serie wydawnicze i ma wspaniałą bibliotekę. Są to wszystko wydawnictwa o dużej renomie w kręgach sinologicznych i o bardzo wysokim poziomie naukowym. Ojciec R. Malek wykłada także na uniwersytecie w Bonn i jest redaktorem naczelnym niemieckiego dwumiesięcznika katolickiego „China Heute”. Jest autorem i redaktorem wielu książek, zbiorów studiów i materiałów, zwłaszcza o chrześcijaństwie w Chinach. Opublikował też wiele studiów, artykułów encyklopedycznych itp. Jest świetnym znawcą taoizmu chińskiego i innych tamtejszych religii. Pomagają mu w redagowaniu polskiego biuletynu O. Antoni Koszorz, SVD, jako redaktor odpowiedzialny, Marek Połomski jako sekretarz redakcji oraz kilku in- 
nych duchownych. Adres redakcji to ul. Skaryszewska 12, 03-802 Warszawa, chinydzisiaj@ecclesia.org.pl

Choć jest to wydawnictwo kościelne korzystać z niego mogą - i chyba nawet powinni - wszyscy nasi nieliczni specjaliści zajmujący się Chinami współczesnymi. Niewatpliwie jest to rezultatem solidnego zaplecza niemieckiego. Redakcja deklaruje nawet otwarcie, że część materiałów tu zamieszczonych pochodzi ze wspomnianego powyżej pisma „China Haute”.

Oczywiście, jako oficjalne wydawnictwo polskiego episkopatu pismo to zamieszcza - w dziale Dokumentacja - ważniejsze dokumenty kościelne, np. w numerze 2, 2007 r. głośny list papieża Benedykta XVI do hierarchii kościelnej i wiernych w ChRL, a obok niego dokumenty historyczne: listy Jana Pawła II do hierarchów Hongkongu. W numerze 3 opublikowano opinie biskupów chińskich na temat tego listu, sygnalizujące spory toczące się wokół niego, a obok nich tekst deklaracji końcowej Międzynarodowego Forum Daodejingu zorganizowanego przez chińskich taoistów i artykuł Ye Xiaowena, dyrektora Narodowego Biura ds. Religii, przedrukowany z z inteligenckiego czasopisma chińskiego z Pekinu „Qiushi” [Poszukiwanie Prawdy]. Autor w duchu obecnej ideologii KPCh omawia pozytywną rolę religii w krzewieniu harmonii społecznej. Jeśli pamiętać, że kieruje on odpowiednikiem naszego dawniejszego Urzędu ds. Wyznań, a dodaje się jeszcze, że poglądy te pan Ye przedstawił także na ostatnim XVII Zjeździe KPCh - publikacja ta jest bardzo znaczącym gestem wobec władz chińskich. Dużo uwagi poświęcono Hongkongowi z okazji 10 rocznicy jego powrotu do macierzy. W ogólnikowo zatytułowanym dziale Tematy omawiano np. ,teologiczną dekolonizację” w tej metropolii, czy problem tożsamości tamtejszych katolików. Są tam omawiane rozmaite kwestie budzace kontrowersje, jak polityczna rola Kościoła w Chinach, znaczenie chrześcijaństwa w ChRL itp.

W wielu materiałach ukazuje się znaczącą poprawę stosunków między Watykanem i Kościołem Katolickim, a władzami ChRL i tamtejszym Kościołem Patriotycznym (np. mianowanie przez ten ostatni biskupów wcześniej zatwierdzonych przez Watykan), chociaż przypomina się też dawniejsze prześladowania i współczesne incydentalne represje. Czytelnik uzyskuje zatem szeroką panoramę złożonych przemian zachodzących w Chinach w sferze religijnej, zwłaszcza odnoszących się do chrześcijaństwa i skomplikowanej sytuacji w tamtejszym kościele katolickim.

Dział Informacje przynosi dość szczegółowe informacje nie tylko o wydarzeniach dotyczących Kościoła Katolickiego w Chinach, ale także tamtejszego Kościoła Patriotycznego, prawosławia, kościołów protestanckich, czy religii chińskich. W tym rozmaite znaczące ciekawostki, jak uruchomienie kaplic do modłów na lotnisku międzynarodowym w Pekinie, czy wydarzenia nawet bardziej znaczące - jak wizyta kardynała z Sajgonu (nominowanego przez Watykan) na zaproszenie władz chińskich, wizytacje panczenlamy, czy zakończenie ramadanu przez muzułmanów chińskich (z dodaniem, że to dla nich dzień wolny od pracy) itd. Ponadto zaś Redakcja sygnalizuje wiele spraw z życia świeckiego, jak np. konflikty rolników z władzami 
w prowincji Guangxi związane z odszkodowaniami za ziemię, restrykcje dotyczące polityki jednego dziecka w rodzinie mimo pewnej liberalizacji w tej sferze, odnotowany w Pekinie wzrost zachorowań na AIDS, czy nawet zwołanie XVII Zjazdu KPCh (wszystkie przykłady z nr 3)! Można jednak wspomnieć, ze nie zawsze autorzy używają nazw zazwyczaj stosowanych, np. zjazdy partyjne za anglosaską tradycją nazywają kongresami.

W dziale Notki historyczne podaje się opisy ważniejszych budynków kościelnych, postaci znaczących dla Kościoła itp. Niekiedy pojawia się jeszcze dział Notatki bibliograficzne, gdzie omawia się nowe publikacje książkowe dotyczące Kościoła chińskiego. Teksty przygotowane przez redaktora naczelnego są zawsze prawdziwą ucztą dla znawcy Chin i nie zawsze dotyczą one tylko spraw kościelnych.

Specjaliści zajmujący się Chinami i osoby interesujące się tym krajem, nie tylko z kręgów katolickich, mają zatem do dyspozycji nowe, bardzo wartościowe wydawnictwo dążące do przedstawiania tego kraju i tamtejszego Kościoła w sposób możliwie obiektywny i nie schematyczny.

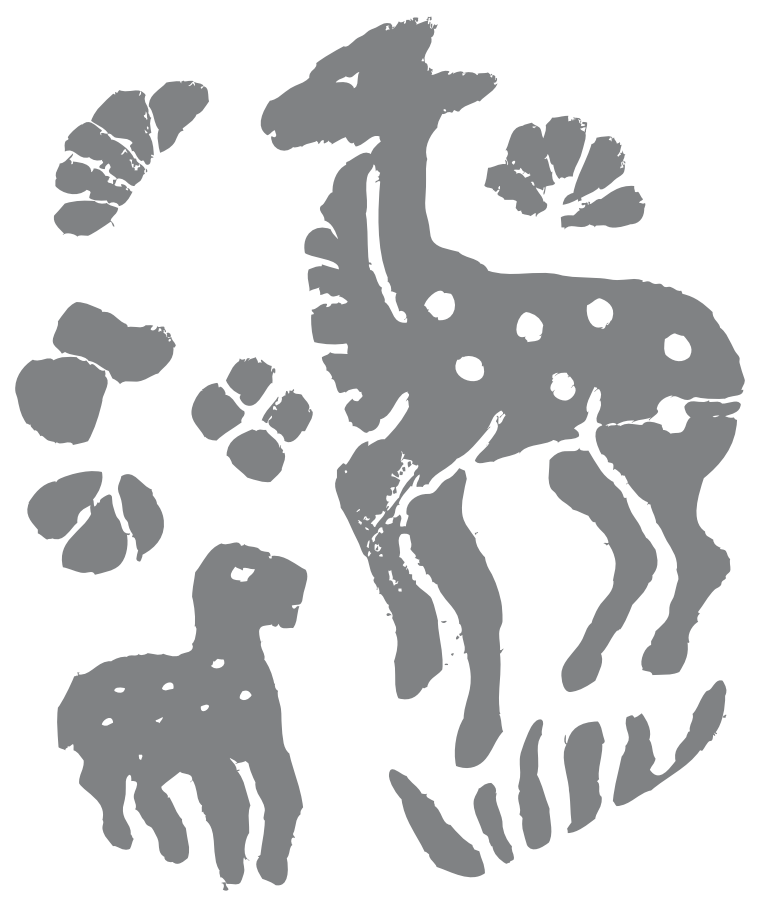

